\title{
Nutrition, Protein/Amino Acids
}

National Cancer Institute

\section{Source}

National Cancer Institute. Nutrition, Protein/Amino Acids. NCI Thesaurus. Code C15920.

Role of proteins and amino acids in cancer causation or prevention and in general health. 